\title{
A Comparative Techno-Economic Analysis of Organic and Conventional Nigella sativa L. Crop Production in Greece
}

\author{
Evangelia STEFANOPOULOU ${ }^{1}$, Ioannis ROUSSIS ${ }^{1}$, Konstantinos TSIMPOUKAS ${ }^{2}$, Stella KARIDOGIANNI ${ }^{1}$, \\ Ioanna KAKABOUKI ${ }^{1}$, Antigolena FOLINA ${ }^{1}$, Dimitrios BILALIS ${ }^{1 *}$
}

${ }^{1}$ Agricultural University of Athens, School of Plant Sciences, Department of Crop Science, Laboratory of Agronomy, 75 Iera Odos St, 11855 Athens, Greece.

${ }^{2}$ Agricultural University of Athens, School of Applied Economics and Social Sciences, Department of Agricultural Economics and Rural Development, Laboratory of Agribusiness Management, 75 Iera Odos St, 11855 Athens, Greece.

*corresponding author: bilalisdimitrios@gmail.com

BulletinUASVM Horticulture 77(1) / 2020

Print ISSN 1843-5254, Electronic ISSN 1843-5394

DOI:10.15835/buasvmcn-hort: 2019.0018

\begin{abstract}
Nigella sativa L. is considered to be an alternative crop offering innovative and high-quality products. A case study was implemented on an existing farm to determine the prospects of $N$. sativa production in Greece and to assess the economic outcomes of the cultivation of this crop under organic and conventional cropping systems. The total production cost of organic $N$. sativa seeds was $6.09 € / \mathrm{kg}$, while the cost of conventional seeds was $4.77 € /$ $\mathrm{kg}$. The organic and conventional $N$. sativa seed selling prices were 17.04 and $12.01 € / \mathrm{kg}$, respectively. Moreover, the financial performance of farm is better after the introduction of $N$. sativa crop under organic cropping system, where the net profit increased by $63.8 \%$ compared to the initial profit of the farm, while the increase in the conventional was less at $49.2 \%$. N. sativa constitutes an alternative crop for enhancing farmer incomes, especially under organic cropping system.
\end{abstract}

Keywords: business plan, cultivation cost analysis, Nigella sativa L., organic farming

\section{Introduction}

The causes of unsustainable agricultural development are well-known, as are the negative impacts on the environment due to greenhouse gas emissions, biodiversity loss, agrochemical pollution, and soil degradation (Reganold and Wachter, 2016). Organic agriculture constitutes a holistic production management system designed to primarily use ecologic processes rather than external inputs to manage crops and livestock. It combines traditional conservation- minded farming methods with modern farming technologies. In addition, organic farming can be a great opportunity for the cultivation of new crops resulting in higher value products and bringing sufficient revenues to enable producers to survive and make a reasonable profit (Karidogianni et al., 2019).

Nigella sativa L. is considered to be an alternative crop offering innovative and highquality products. It is a species of Ranunculaceae family native to southern Europe, North Africa, 
and South and West Asia. The seeds are commonly known as black seed or black cumin and contain oils (30-35\% fixed and $0.5-1.5 \%$ essential), proteins, alkaloids and saponins. N. sativa seeds and its essential oil have been widely used in functional foods and nutraceutical products (Roussis et al., 2017). In the past, the seeds of N. sativa were used as a spice in the Balkans Peninsula especially for bread. Moreover, the seeds have been accepted as a source of aroma in the "blue book" of European Council from 1981 and granted a claim as a novel food ingredient in the context of Regulation (EC) No. 258/97 (EC, 2019).

The biggest producer of $N$. sativa in 2015 was India, accounting for more than $85 \%$ of the world productions, followed by Sri Lanka, Bangladesh, Nepal, Egypt, Iraq, Pakistan, and Turkey (Lal, 2018). Almost all the N. sativa producing countries are developing nations and major producers are small and marginal farmers. Exact information on its area of cultivation and annual production is not available; however, it is estimated to be produced in an area of about 9000 ha with a production of about 7000-8000 tonnes in India. The main importing regions are East Asia, EU, Malaysia, USA, and Canada (Malhotra, 2004).

The increasing consumer awareness for the healthy lifestyle and herbal products is driving the global market growth (Pocol et al., 2016; Ahuja and Singh, 2019). Growing demand for pharmaceutical, cosmetic, and nutraceutical products is likely to propel $N$. sativa market size in the next five years. Nutraceuticals market is forecast to surpass 550 billion USD by 2025 . As a result, $N$. sativa oil market revenue is forecast to exceed 25 million USD at the end of 2025 (Ahuja and Singh, 2019).

The present study aimed to determine the prospects of $N$. sativa production in Greece as a new crop and to assess the economic outcomes of the cultivation of this crop under organic and conventional cropping systems.

\section{Materials and Methods}

A case study was implemented on an existing farm in Aliartos area situated in Viotia regional unit of Central Greece region. For the comparative analysis of organic and conventional $N$. sativa crop production, two business plans were developed, one for each farming system. The total area of the studied farm was 40 ha and originally grown durum wheat. The $N$. sativa crop was introduced in an area of 4 ha. The business plan for each type of cropping system included 36 ha of durum wheat and 4 ha of $N$. sativa. The business plan in the case of organic $N$. sativa cultivation was a 5 -year including the organic transition period (the first 3 years). Additionally, a SWOT analysis (strengths, weaknesses, opportunities and threats analysis) was performed to identify the internal and external factors that can have an effect on viability of N. sativa crop production in Greece.

The analysis of economic results was based on the tables of annual depreciation and annual expenditure calculations, provided by Hellenic Statistical Authority (ELSTAT, 2019). The average N. sativa seed yield was estimated at 550 and 700 $\mathrm{kg} \mathrm{ha}^{-1}$ for organic and conventional production, respectively (Roussis et al., 2019). The economic results were calculated by applying the following formulas:

Gross Annuity = Total Sales Value + Total Subsidies (1)

Net Profit = Gross Annuity - Production Costs

Gross Profits = Gross Annuity - Total Variable Costs (3)

Agricultural Farmer's Income = $=$ Gross Annuity - Total Apparent Costs (4)

Net Annuity $=$ Net Profit + Interest + Rent

For the comparison between the economic results of the different cultivation systems, the data of the fourth year of organic $N$. sativa cultivation (the first year of certified organic production) were used, as the first year of the production was considered conventional, the second and third were transitional, while the fifth year presented the similar results as the fourth year.

\section{Results and Discussion}

The total production costs of organic $N$. sativa seeds were $1.72 € \mathrm{~kg}^{-1}$ higher than the production costs of conventional seeds (Tab. 1) since, there were additional costs associated with the certification of organic production and the consumables (e.g. the greater use of field machinery) (Karidogianni et al., 2019). The consumable costs in organic seed production were $1.04 €$ per kg compared to $0.77 €$ in conventional production. The labor costs for the production of $1 \mathrm{~kg}$ organic $N$. sativa seed were $0.05 €$ higher than in conventional farming. 
Table 1. Annual production costs of organic and conventional N. sativa production

\begin{tabular}{|c|c|c|}
\hline Production Items & Organic $(€ /$ ha) & Conventional $(€ / \mathrm{ha})$ \\
\hline \multicolumn{3}{|l|}{ A. Land } \\
\hline i. Land rent & 300.00 & 300.00 \\
\hline \multicolumn{3}{|l|}{ B. Labor } \\
\hline i. Unpaid (Farmer's family) labor & 39.30 & 33.21 \\
\hline ii. Paid labor & 32.46 & 32.21 \\
\hline iii. Accrued interest income & 3.23 & 2.94 \\
\hline \multicolumn{3}{|l|}{ C. Capital } \\
\hline \multicolumn{3}{|l|}{ i. Fixed Capital } \\
\hline a) Amortization & 464.00 & 464.00 \\
\hline b) Fixed capital interests & 659.49 & 791.73 \\
\hline c) Maintenance & 208.26 & 250.02 \\
\hline d) Insurance premiums & 6.94 & 16.28 \\
\hline $\begin{array}{l}\text { e) Maintenance \& Insurance premiums } \\
\text { interests }\end{array}$ & 9.69 & 15.00 \\
\hline \multicolumn{3}{|l|}{ ii. Circulating Capital } \\
\hline $\begin{array}{c}\text { a) Consumables (Seeds, } \\
\text { Fertilizers, Fuels etc.) } \\
\end{array}$ & 570.50 & 540.35 \\
\hline $\begin{array}{l}\text { b) Contributions to Greek Agricultural } \\
\text { Insurance Organization (ELGA) }\end{array}$ & 280.50 & 252.00 \\
\hline c) Third party services & 337.50 & 337.50 \\
\hline d) Other costs & 368.75 & 243.75 \\
\hline e) Circulating capital interest & 70.08 & 63.17 \\
\hline \multirow{2}{*}{ Total Production Costs } & $3,350.69$ & $3,342.16$ \\
\hline & 6.09 & 4.77 \\
\hline
\end{tabular}

Concerning the selling price, the organic $N$. sativa seeds were $41.7 \%$ more expensive than conventional (17.04 and $12.01 € \mathrm{~kg}^{-1}$ for organic and conventional cropping system, respectively). A similar trend was also observed in an economic analysis of soybean production, where the organic soybeans were $50 \%$ more expensive than conventional $\left(0.6\right.$ and $0.4 € \mathrm{~kg}^{-1}$ for organic and conventional, respectively) (Karidogianni et al., 2019). It is also worth noting that the EU's Common Agricultural Policy is designed to support organic farming by giving high subsidies (EC, 2013).

The net profit of $N$. sativa cultivation was 23,997 and $19,968 €$ in the organic and conventional farming system, respectively (Tab. 2). By comparison, the financial performance of farm is better after the introduction of $N$. sativa crop. This is shown by the final net profit increased by $63.8 \%$ and $49.2 \%$ under organic and conventional $N$. sativa cultivation as compared to the initial net profit of the farm $(27,622 €$; data not shown). In addition, the net profit of organic $N$. sativa production accounted for $53.0 \%$ of the total net profit of the farm. Regarding the seed yield of $N$. sativa under organic cropping system, it is $21.4 \%$ lower than under conventional system (Roussis et al., 2019).

According to the SWOT analysis, the strongest points of $N$. sativa cultivation are the high production capability, the high selling prices as well as the reduced competition for $N$. sativa seeds and oils worldwide due to the small total world production of this plant species. The biggest weaknesses are the lack of certified seeds as well as the lack of know-how (Tab. 3).

\section{Conclusions}

The present study revealed that in both types of $N$. sativa cultivation the results of techno-economic analysis attested to a positive convenience; however, $N$. sativa crop production under organic cropping system is more advantageous providing a financially competitive alternative to conventional ones, offsetting the 
Table 2. Annual economic outcomes of $N$. sativa cultivation (4 ha) and studied farm (36 ha durum wheat and 4 ha $N$. sativa) under organic and conventional farming systems

\begin{tabular}{ccccc}
\hline \multirow{2}{*}{ Economic outcomes } & \multicolumn{2}{c}{ Organic } & \multicolumn{2}{c}{ Conventional } \\
\cline { 2 - 5 } & N. sativa $(€)$ & Farm (€) & N. sativa (€) & Farm (€) \\
\hline Gross annuity & 37,400 & 90,148 & 33,600 & 86,348 \\
\hline Net profit & 23,997 & 45,245 & 19,968 & 41,216 \\
\hline Gross profits & 30,761 & 66,347 & 27,729 & 63,585 \\
\hline Agricultural farmer's income & 28,234 & 57,796 & 24,787 & 54,349 \\
\hline Net annuity & 28,154 & 61,494 & 24,642 & 57,802 \\
\hline
\end{tabular}

Table 3. SWOT analysis for $N$. sativa cultivation in Greece

\begin{tabular}{cc}
\hline Strengths & Weaknesses \\
\hline $\begin{array}{c}\text { High production capability } \\
\text { High prices } \\
\text { Reduced competition }\end{array}$ & $\begin{array}{c}\text { Lack of certified seeds } \\
\text { Lack of know-how }\end{array}$ \\
\hline Opportunities & Threats \\
\hline $\begin{array}{c}\text { High demand for } N \text {. sativa seeds and oils worldwide } \\
\text { Opportunities for growth and progress } \\
\text { Increased profits }\end{array}$ & Mainly loss of production due to natural disasters \\
\hline
\end{tabular}

lower yields. Therefore, $N$. sativa constitutes an alternative crop for enhancing farmer incomes, especially under organic cropping system.

\section{References}

1. Ahuja K, Singh S (2019). Black Seed Oil Market Size, By Form Type (Capsule, Oil), By Application (Personal Care \& Cosmetics [Skin care, Hair care, Fragrances], Pharmaceuticals, Nutraceutical [Food supplement/ Dietary supplement, Functional Food], Flavoring \& Dressing, Culinary), Regional Outlook (U.S., Canada, Mexico, Germany, UK, France, Italy, Russia, Spain, Switzerland, Belgium, China, India, Japan, South Korea, Malaysia, Thailand, Indonesia, Australia, Brazil, UAE, Saudi Arabia, Turkey, Egypt, South Africa), Price Trend, Competitive Market Share \& Forecast, 2019 - 2025. Global Market Insights, Inc. Report ID: GMI3085. https://www. gminsights.com/industry-analysis/black-seed-oil-market Accessed 04.09.19.

2. Hellenic Statistical Authority (ELSTAT) Statistics Agriculture, Livestock and Fishery (2019). http://www. statistics.gr/en/statistics/agr Accessed 04.09.19.

3. European Commision (EC). The common agricultural policy (CAP) and agriculture in Europe - Frequently asked questions (2013). https://ec.europa.eu/commission/ presscorner/detail/en/MEMO_13_631. Accessed 05.09.19.

4. European Commission (EC). EU Novel food catalogue (v.1.1) (2019). http://ec.europa.eu/food/safety/novel_ food/catalogue/search/public/?event=home\&seqfce $=22$ 6\&ascii $=\mathrm{N}$ Accessed 04.09.19.

5. Karidogianni S, Roussis I, Tsimpoukas K, Papastylianou P, Bilalis D (2019). Comparative technical and economic analysis of organic and conventional soybean production in Greece. Bulletin UASVM Horticulture, 76(1): 79-82.

6. Lal G (2018). Scenario, importance and prospects of seed spices: A review. Current Investigations in Agriculture and Current Research, 4(2): 491-498.

7. Malhotra SK (2004). Nigella. In: Peter KV (Ed.), Handbook of herbs and spices, Vol. 2. Woodhead Publishing Limited, Cambridge, UK, pp. 219-242.

8. Pocol CB, Moldovan Teselios C, Stan L, Pop ID (2016). Alfalfa powder: Healthy food supplement for sustainable consumption. Problems of World Agriculture/Problemy Rolnictwa Światowego, 16(4):7-17.

9. Reganold JP, Wachter JM (2016). Organic agriculture in the twenty-first century. Nature Plants, 2: 15221.

10. Roussis I, Kakabouki I, Bilalis D (2019). Comparison of growth indices of Nigella sativa L. under different plant densities and fertilization. Emirates Journal of Food and Agriculture, 31(4): 231-247.

11. Roussis I, Travlos I, Bilalis D, Kakabouki I (2017). Influence of seed rate and fertilization on yield and yield components of Nigella sativa L. cultivated under Mediterranean semi-arid conditions. AgroLife Scientific Journal, 6(1): 218-223. 